\title{
Affinity purified anti-citrullinated protein/peptide antibodies target antigens expressed in the rheumatoid joint
}

\author{
Elena Ossipova ${ }^{1 \dagger}$, Cátia Fernandes Cerqueira ${ }^{1 \dagger}$, Evan Reed ${ }^{1}$, Nastya Kharlamova $^{1}$, Lena Israelsson ${ }^{1}$, \\ Rikard Holmdahl ${ }^{2}$, Kutty Selva Nandakumar ${ }^{2}$, Marianne Engström', Ulrike Harre ${ }^{3}$, Georg Schett ${ }^{3}$, Anca I Catrina', \\ Vivianne Malmström¹, Yngve Sommarin ${ }^{4}$, Lars Klareskog ${ }^{1}$, Per-Johan Jakobsson ${ }^{1}$ and Karin Lundberg ${ }^{1,5^{*}}$
}

\begin{abstract}
Introduction: A major subset of patients with rheumatoid arthritis (RA) is characterized by the presence of circulating autoantibodies directed to citrullinated proteins/peptides (ACPAs). These autoantibodies, which are commonly detected by using an enzyme-linked immunosorbent assay (ELISA) based on synthetic cyclic citrullinated peptides (CCPS), predict clinical onset and a destructive disease course. In the present study, we have used plasma and synovial fluids from patients with RA, for the affinity purification and characterization of anti-CCP2 reactive antibodies, with an aim to generate molecular tools that can be used in vitro and in vivo for future investigations into the pathobiology of the ACPA response. Specifically, this study aims to demonstrate that the surrogate marker CCP2 can capture ACPAs that bind to autoantigens expressed in vivo in the major inflammatory lesions of RA (that is, in the rheumatoid joint).
\end{abstract}

Methods: Plasma $(n=16)$ and synovial fluid $(n=26)$ samples were collected from RA patients with anti-CCP2 IgG levels of above $300 \mathrm{AU} / \mathrm{mL}$. Total IgG was isolated on Protein G columns and subsequently applied to CCP2 affinity columns. Purified anti-CCP2 IgG was analyzed for reactivity and specificity by using the CCPlus ${ }^{\circledR}$ ELISA, in-house peptide ELISAs, Western blot, and immunohisto-/immunocytochemistry.

Results: Approximately $2 \%$ of the total lgG pool in both plasma and synovial fluid was CCP2-reactive. Purified anti-CCP2 reactive antibodies from different patients showed differences in binding to CCP2 and differences in binding to citrullinated peptides from a-enolase, vimentin, fibrinogen, and collagen type II, illustrating different ACPA fine-specificity profiles. Furthermore, the purified ACPA bound not only in vitro citrullinated proteins but, more importantly, in vivo-generated epitopes on synovial fluid cells and synovial tissues from patients with RA.

Conclusions: We have isolated ACPAs from plasma and synovial fluid and demonstrated that the CCP2 peptides, frequently used in diagnostic ELISAs, de facto act as surrogate antigens for at least four different, well-characterized, largely non-cross-reactive, ACPA fine specificities. Moreover, we have determined the concentration and proportion of CCP2-reactive lgG molecules in rheumatoid plasma and synovial fluid, and we have shown that the purified ACPAs can be used to detect both in vitro- and in vivo-generated citrullinated epitopes by various techniques. We anticipate that these antibodies will provide us with new opportunities to investigate the potential pathogenic effects of human ACPAs.

\footnotetext{
* Correspondence: karin.lundberg@ki.se

${ }^{\dagger}$ Equal contributors

${ }^{1}$ Rheumatology Unit, Department of Medicine, Karolinska Institutet, CMM L8:04, Karolinska University Hospital Solna, 17176 Stockholm, Sweden

${ }^{5}$ Postal address: Rheumatology Unit, Department of Medicine, Karolinska Institutet, Karolinska University Hospital Solna, CMM L8:04, Karolinska University Hospital Solna, 17176 Stockholm, Sweden

Full list of author information is available at the end of the article
} 


\section{Introduction}

Autoimmunity in a major subset of patients with rheumatoid arthritis (RA) is characterized by the presence of disease-specific autoantibodies directed against posttranslationally citrullinated proteins/peptides (ACPAs) [1-3]. These antibodies can be detected years before clinical manifestations of arthritis $[4,5]$, their presence predicts a more erosive disease course [6], and an enrichment in the joints compared with the circulation [7] suggests a local production and a pathogenic involvement. However, relatively little is known about the potential pathogenic effects of the human ACPA response. Hence, more in-depth molecular studies of ACPAs are warranted. To facilitate such future investigations, we have in the present study isolated and characterized ACPAs from RA synovial fluid (SF) and plasma.

Routine testing for ACPAs in clinical practice is commonly performed by using a commercial enzyme-linked immunosorbent assay (ELISA) based on cyclic citrullinated peptides (CCPs), the so-called "second generation" anti-CCP ELISA [2]. Today, this assay constitutes an important diagnostic tool for RA and is also widely used in research studies on ACPAs. However, anti-CCP2 reactive antibodies target synthetic peptides that do not correspond to any human protein sequence, and thus these antibodies act as surrogate markers for autoimmunity in RA without formally defining any reactivity against autoantigens present in vivo.

We and others have investigated the fine specificity of the ACPA response [8-12] and demonstrated reactivity to citrullinated epitopes on proteins expressed in the rheumatoid joint, including $\alpha$-enolase [13,14], fibrinogen [15], vimentin [16], collagen type II (CII) [17], immunoglobulin binding protein (BiP) [18], annexin [19], and histone 4 [20]. The frequencies of ACPAs reactive with single autoantigen-derived peptides are in most patient cohorts lower than the frequency of anti-CCP2 reactive antibodies, whereas the number of RA patients who are positive for any of these ACPA fine specificities is similar to the number of anti-CCP2-positive patients (typically around $60 \%$ to $70 \%$ [ [21]. Notably, reactivity to the autoantigen-derived citrullinated peptides can also be detected in a minor subset of anti-CCP2-negative patients. Peptide-absorption experiments demonstrate limited crossreactivity between different ACPA fine specificities, and different ACPA-reactivity patterns can be seen in different patients [10-12,21].

Whether the same antibodies that react with the CCP2 peptides used in the diagnostic ELISA also react with citrullinated antigens expressed in tissues and cells from rheumatoid joints, including the four most extensively studied ACPA targets (citrullinated $\alpha$-enolase, vimentin, fibrinogen, and collagen type II), has never been formally demonstrated (with the exception of citrullinated fibrinogen) [22]. A prerequisite for such studies involves the isolation of human anti-CCP2 reactive antibodies. Hence, in the present study, where we have affinitypurified ACPAs on CCP2 columns, we have had the opportunity to investigate the reactivity of anti-CCP2 IgG in detail. We have also been able to determine the concentration and proportion of CCP2-reactive IgG molecules in rheumatoid plasma and SF; importantly, we have demonstrated that the purified ACPAs can be used as molecular tools for the detection of in vitro- and in vivo-generated citrullinated epitopes by ELISA, Western blot, and immunohisto-/immunocytochemistry.

\section{Materials and methods \\ Patients}

Non-paired synovial fluid $(n=26)$ and plasma $(n=16)$ samples were collected with informed consent from RA patients attending the rheumatology clinic at Karolinska University Hospital, Stockholm, Sweden, from 2001 to 2011. Synovial fluid was collected from patients requiring arthrocentesis. All patients fulfilled the American College of Rheumatology/European League Against Rheumatism criteria for RA [23-25] and were selected on the basis of having high anti-CCP2 antibody levels $(>300 \mathrm{AU} / \mathrm{mL})$. Samples were stored at $-20^{\circ} \mathrm{C}$ (short term) or $-80^{\circ} \mathrm{C}$ (long term) until processed. The study was approved by the regional ethics committee at Karolinska Institutet.

\section{Affinity purification of human anti-CCP2 lgG}

Synovial fluid (10 to $20 \mathrm{~mL}$ per sample) was centrifuged at 4,000 rpm before supernatants were treated with hyaluronidase (Sigma-Aldrich, St. Louis, MO, USA) for 1 hour at $4^{\circ} \mathrm{C}$ in order to decrease viscosity. Proteins were precipitated by using saturated ammonium sulphate in accordance with standard protocol [26], dissolved in phosphate-buffered saline (PBS), and further dialyzed against PBS. Plasma (15 to $25 \mathrm{~mL}$ per sample) was centrifuged and diluted 1:5 ( $\mathrm{vol} / \mathrm{vol})$ in PBS. IgGs from plasma and SF were purified on HiTrap Protein G HP columns (GE Healthcare, Stockholm, Sweden) in accordance with the instructions of the manufacturer. Eluted IgG fractions were dialyzed against PBS and filtered before being applied to the CCP2 affinity column, kindly provided by Euro-Diagnostica $\mathrm{AB}$ (Malmö, Sweden). The CCP2 column was subsequently washed with 10 column volumes of PBS before bound antiCCP2 IgG was eluted by using $0.1 \mathrm{M}$ glycine- $\mathrm{HCl}$ buffer $(\mathrm{pH}$ 2.7) and directly neutralized with $1 \mathrm{M}$ Tris $(\mathrm{pH} 9)$ (Figure 1). Buffer exchange to PBS and concentration of antibodies was performed in one step, applying the 10kDa Microsep ${ }^{\mathrm{Tm}}$ UF Centrifugal Device (Pall Life Science, Port Washington, NY, USA) in accordance with the instructions of the manufacturer. 


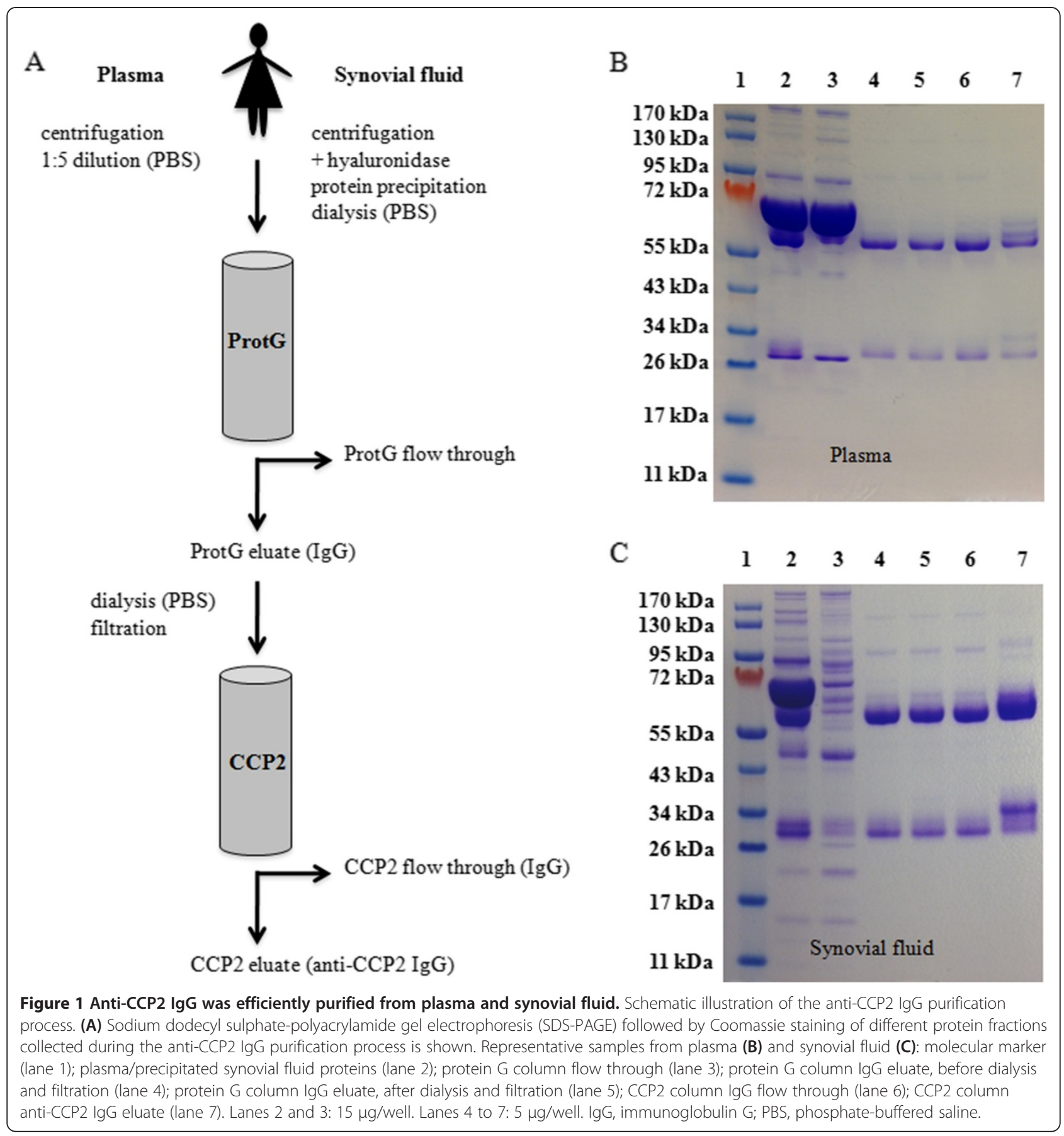

\section{CCP2 column}

CCP2 peptides $(2 \mathrm{mg}$ ) (corresponding to the patentprotected peptides used in the commercially available Immunoscan CCPlus ${ }^{\circledast}$ assay from Euro-Diagnostica $\mathrm{AB}$ ) were coupled to $1 \mathrm{~mL}$ HiTrap columns (GE Healthcare). Recommended flow rate and backpressure specifications were followed (flow rate: $1 \mathrm{~mL} / \mathrm{min}$, maximum backpressure: $0.3 \mathrm{MPa}$ ). Performance of the columns was typically around $1 \mathrm{mg}$ anti-CCP2 IgG/column.

\section{Calculations of total IgG and anti-CCP2 IgG concentrations} in plasma and SF

Protein concentrations were determined in Protein G column eluate fractions (before and after dialysis and filtration) and in CCP2 column flow-through and eluate fractions by using the Bradford DC assay (Bio-Rad Laboratories, Hercules, CA, USA) and the Nanodrop Spectrophotometer (Thermo Scientific, Waltham, MA, USA) in parallel in accordance with the instructions of 
the manufacturers. The concentration (in milligrams per milliliter) of total IgG was calculated on the basis of the initial plasma or SF volume applied to the Protein G column and the amount of IgG eluted from the Protein G column (that is, before dialysis and filtration). The proportion (percentage) of anti-CCP2 IgG (of total IgG) was calculated on the basis of the amount of IgG applied to the CCP2 column (that is, after dialysis and filtration) and the amount of anti-CCP2 IgG eluted from the CCP2 column. The concentration (in milligrams per milliliter) of anti-CCP2 IgG was then calculated on the basis of this proportion (percentage) in relation to the concentration (in milligrams per milliliter) of total IgG in plasma and SF.

\section{SDS-PAGE}

Recovery and purity of total IgG and anti-CCP2 IgG were analyzed by Coomassie brilliant blue staining after protein separation on sodium dodecyl sulphate-polyacrylamide gel electrophoresis (SDS-PAGE). In brief, samples were diluted in lithium dodecyl sulphate (LDS) sample buffer (Invitrogen, Carlsbad, CA, USA) containing dithiothreitol (DTT) and subjected to denaturation and reduction at $70^{\circ} \mathrm{C}$ for 10 minutes. Plasma, precipitated SF proteins, Protein G column flow-through fractions (at $15 \mu \mathrm{g} / \mathrm{well}$ ), Protein G column eluate fractions (before and after dialysis and filtration), and CCP2 column flow-through and eluate fractions (at $5 \mu \mathrm{g} /$ well) were loaded onto NuPAGE ${ }^{\circ}$ Bis-Tris 4\%-12\% gels (Invitrogen) and run in 2-( $N$-morpholino)ethanesulfonic acid (MES)-SDS antioxidant-containing running buffer at $200 \mathrm{~V}$ (constant) for 45 minutes. Protein bands were visualized by Coomassie brilliant blue staining (0.2\% Comassie blue, $7.5 \%$ glacial acetic acid, $50 \%$ methanol) in accordance with standard protocol.

\section{ELISAs}

Anti-CCP2 reactivity was determined in 10 plasma and $11 \mathrm{SF}$ samples and in the corresponding fractions collected during the anti-CCP2 IgG purification process (as described above). Samples were analyzed in duplicates and in serial dilutions $(7 \times 1: 3$ dilution steps $)$ starting at $1: 100$ (plasma and SF) or at $10 \mu \mathrm{g} / \mathrm{mL}$ (fractions) by using the Immunoscan CCPlus ${ }^{\circ}$ assay (Euro-Diagnostica $\mathrm{AB})$ in accordance with the instructions of the manufacturer. Cutoff for positivity was $25 \mathrm{AU} / \mathrm{mL}$. Reactivities to citrullinated peptides from $\alpha$-enolase (CEP-1; amino acid 5-21), vimentin (Cit-vim; amino acid 60-75), fibrinogen (Cit-fib; amino acid 36-52), and collagen type II (Cit-C1; amino acid 359-369) were assayed in the same samples at the same dilutions by using in-house ELISAs as previously described [21]. Cutoff for positivity was calculated on the basis of the 98th percentile among 150 healthy controls and set to $10 \mathrm{AU} / \mathrm{mL}$ for all ACPA fine specificities.

\section{Western blot}

Purified human fibrinogen (Merck, Darmstadt, Germany) depleted of immunoglobulins, recombinant human $\alpha$ enolase, and recombinant mutated human vimentin were citrullinated in vitro by using rabbit skeletal muscle peptidylarginine deiminase 2 (PAD2) (Sigma-Aldrich) as previously described [27]. Citrullinated and uncitrullinated proteins $(1 \mu \mathrm{g} /$ well $)$ were separated on NuPAGE ${ }^{\oplus}$ Bis-Tris $10 \%$ gels (Bio-Rad Laboratories), stained with Coomassie brilliant blue, or transferred to nitrocellulose membranes. Membranes were blocked with 5\% milk, tris-buffered saline (TBS)/0.05\% Tween, probed with a pool of 11 purified antiCCP2 IgG eluate fractions from SF, or the corresponding CCP2 column flow-through IgG pool, at $2 \mu \mathrm{g} / \mathrm{mL}$, for 1 hour at room temperature (RT), before being washed in PBS/0.05\% Tween and incubated with horseradish peroxidase (HRP)-conjugated goat anti-human IgG (The Jackson Laboratory, Bar Harbor, ME, USA), diluted 1:20,000, for 1 hour at RT. After a final wash, membranes were subjected to enhanced chemiluminescence (ECL) development.

\section{Immunohisto-/immunocytochemistry}

Synovial hip or knee biopsy specimens were obtained from three patients with RA by joint replacement surgery and were snap-frozen in dry ice-cool isopentane; serial cryostat sections $(7 \mu \mathrm{m})$ were fixed with $2 \%$ (vol/vol) formaldehyde and stored at $-80^{\circ} \mathrm{C}$ before being stained. Fresh SF mononuclear cells from three patients with RA were prepared by ficoll separation and fixed in $2 \%$ formaldehyde before being stained. The presence of citrullinated epitopes was detected by using a pool of 26 purified anti-CCP2 IgG eluate fractions from SF and the corresponding flow-through IgG pool. The antibody pools were biotinylated (Lightning-Link $^{\mathrm{Tm}}$ Biotin conjugation kit; Innova Biosciences, Cambridge, UK) and used at $10 \mu \mathrm{g} / \mathrm{mL}$ for staining synovial tissue or at $5 \mu \mathrm{g} / \mathrm{mL}$ for staining SF cells. PBS/saponine was used to permeabilize the cells. The vectastain detection system (ABC-elite kit, Vector Laboratories, Burlingame, CA, USA) was used for the tissue, and Streptavidin/HRP (DakoCytomation, Glostrup, Denmark) was used for the cells.

\section{Statistical analyses}

Differences in antibody levels (in arbitrary units per milliliter) between different ACPA fine specificities in plasma and SF and in the purified anti-CCP IgG2 eluate fractions were examined by using Mann-Whitney $U$ test for independent groups.

\section{Results}

\section{Efficient purification of anti-CCP2 lgG on CCP2 affinity} columns

Anti-CCP2 IgG was efficiently purified from 16 plasma and 26 SF samples by using Protein G and CCP2 affinity 
columns (Figure 1A). Fractions collected during the purification process were analyzed by Coomassie staining after separation on SDS-PAGE (Figure 1B and C). IgG isolation on the protein G column was confirmed to efficiently remove non-IgG materials. No degradation, and only minor loss of protein content $(<6 \%)$, was observed during the dialysis and filtration step (data not shown). The CCP2 affinity columns demonstrated high capacity regarding the amount of target-protein loaded, and no destructive processes were detected during the elution, yielding pure and intact anti-CCP2 IgG with high recovery. The multiple bands around the molecular weight of the IgG heavy and light chains, seen mainly in the CCP2 eluate fractions from both plasma and SF, may represent different isoforms and modifications (for example, glycosylation [28]) of the IgG molecules.

\section{Concentration and proportion of anti-CCP2 IgG in plasma and synovial fluid}

By measuring the protein concentration at every step of the purification process, we have calculated the concentration of anti-CCP2 IgG in the circulation and locally in the joint (Table 1). The concentration of anti-CCP2 IgG was higher in plasma (median value of $0.2 \mathrm{mg} / \mathrm{mL}$ ) than in SF (median value of $0.06 \mathrm{mg} / \mathrm{mL}$ ), but since the concentration of total IgG was also higher in plasma (median value of $14.6 \mathrm{mg} / \mathrm{mL}$ ) compared with SF (median value of $3.5 \mathrm{mg} / \mathrm{mL}$ ), in line with what has previously been described [29,30], the proportion of IgG molecules with CCP2 reactivity was in fact marginally higher in SF (median value of 2.2\%, with four samples above 6\%) than in plasma (median value of $1.5 \%$ and a highest recorded proportion of 3.6\%).

\section{Anti-CCP2 IgG contain ACPA of various fine specificities}

Anti-CCP2 reactivity was monitored throughout the purification process by using the Immunoscan CCPlus $^{\circ}$ ELISA. No anti-CCP2 IgG response could be detected in any of the Protein G or CCP2 column flow-through fractions, whereas strong CCP2 reactivity was recorded in all Protein G column eluate fractions and in all CCP2 column eluate fractions (data not shown). The purified anti-CCP2 IgG eluate fractions as well as the corresponding flow-through fractions from 10 plasma and
11 SF samples were further tested (by ELISA) in serial dilutions for reactivity with CCP2 as well as four wellcharacterized ACPA epitopes on citrullinated $\alpha$-enolase (CEP-1), vimentin (Cit-vim), fibrinogen (Cit-fib), and collagen type II (Cit-C1). Differences in binding capacity to CCP2 were observed between anti-CCP2 IgG purified from different patients, as demonstrated by marked differences in absorption (that is, $\mathrm{AU} / \mathrm{mL}$ values) between samples, despite being analyzed at the same antibody concentration (Figure 2). A large majority of CCP2 column eluate fractions from both plasma and SF was positive for all four ACPA fine specificities (Table 2 and Figure 2), whereas the flow-through fractions were consistently negative (data not shown).

Five plasma samples and $10 \mathrm{SF}$ samples were considered negative for one or several ACPA fine specificities on the basis of the cutoff value for positivity of $10 \mathrm{AU} /$ $\mathrm{mL}$. Still, purified anti-CCP2 IgGs from these samples were considered positive (that is, above the cutoff value for positivity) (Table 2). The reason for this discrepancy is most likely due to differences in ACPA concentrations between the purified anti-CCP2 IgG eluates, which were tested at $10 \mu \mathrm{g} / \mathrm{mL}$, and the original "pre" plasma and SF samples, which were tested at a lower concentration (that is, a dilution of 1:100).

No correlations could be observed between strong CCP2-binding and presence of specific ACPA finespecificity patterns. In fact, several anti-CCP2 IgG eluates with weak binding to CCP2 seemed to have particularly strong binding to CEP-1 (Figure 2). Moreover, purified anti-CCP2 IgG from SF showed significantly stronger reactivity with CEP-1 compared with the other citrullinated peptides $(P<0.01)$. Median reactivities were $447 \mathrm{AU} / \mathrm{mL}$ for anti-CEP-1 and 40, 97, and $62 \mathrm{AU} / \mathrm{mL}$ for anti-Citvim, anti-Cit-fib, and anti-Cit-C1, respectively (Table 2). This observation was mirrored by significantly higher anti-CEP-1 IgG levels in the original "pre" SF samples compared with the other ACPA fine specificities. This anti-CEP-1 "enrichment" was specific for SF and could not be seen in plasma/anti-CCP2 IgG purified from plasma.

Reactivity of the purified ACPA was further analyzed by Western blot, in which a pool of 11 purified antiCCP2 IgG eluate fractions from SF bound in vitro-

Table 1 Concentrations and proportion of anti-CCP2 IgG in plasma and synovial fluid

\begin{tabular}{|c|c|c|c|c|}
\hline & \multicolumn{2}{|c|}{ Plasma $(n=16)$} & \multicolumn{2}{|c|}{ SF $(n=26)$} \\
\hline & Median & Range & Median & Range \\
\hline Total lgG concentration, mg/mL & 14.6 & $6.5-25.7$ & 3.5 & $0.9-15.2$ \\
\hline Anti-CCP lgG concentration, mg/mL & 0.2 & $0.05-0.5$ & 0.06 & $0.01-0.2$ \\
\hline Proportion of anti-CCP IgG, \% ${ }^{\mathrm{a}}$ & 1.5 & $0.4-3.6$ & 2.2 & $0.1-15.6$ \\
\hline
\end{tabular}

${ }^{a}$ Calculated as the percentage of anti-CCP2 IgG of total IgG. CCP, cyclic citrullinated peptide; lgG, immunoglobulin G; SF, synovial fluid. 


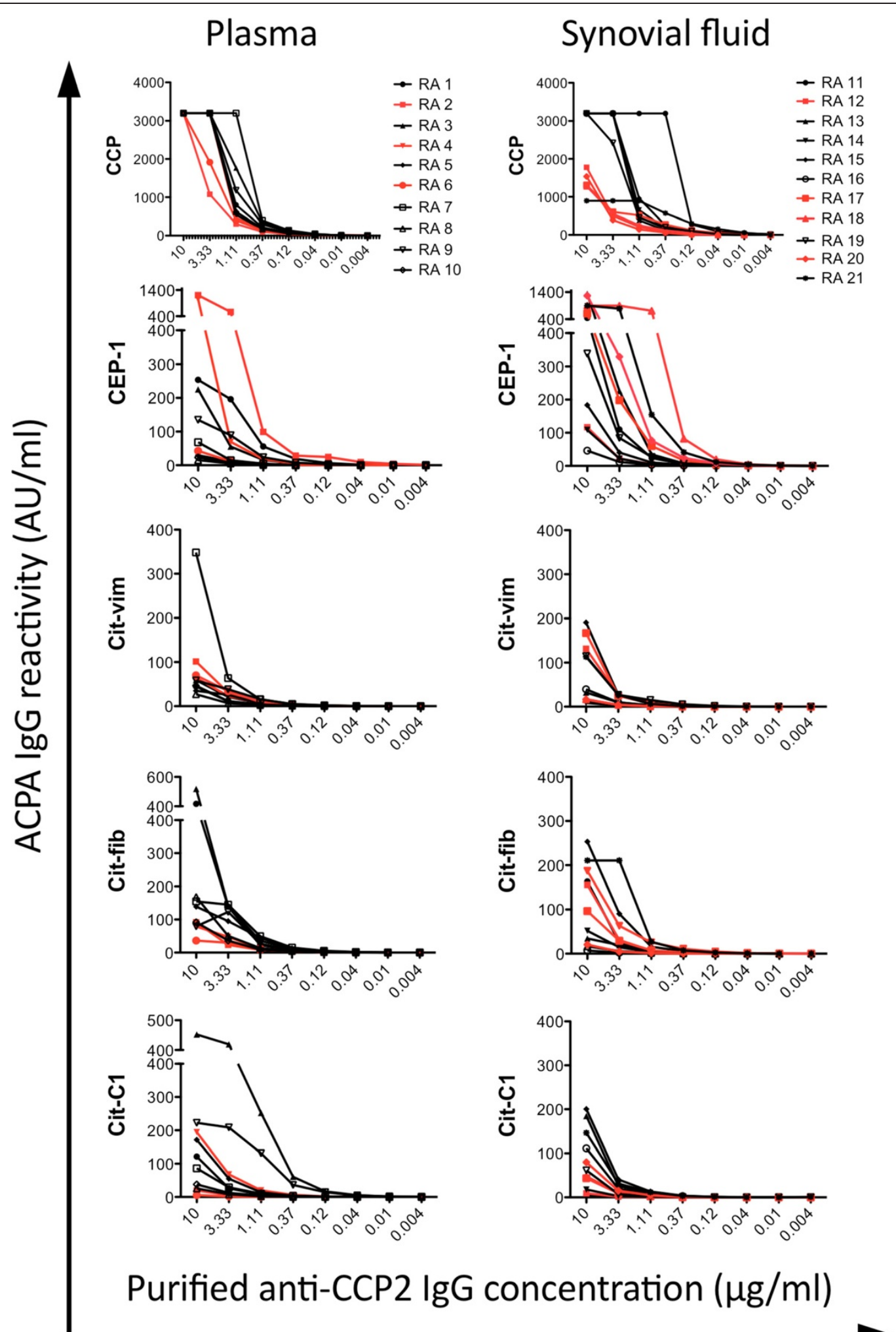

Figure 2 (See legend on next page.) 
(See figure on previous page.)

Figure 2 Anti-CCP2 IgG contains autoantibodies directed to citrullinated proteins/peptides (ACPAs) of various fine specificities. Analysis was conducted by enzyme-linked immunosorbent assay (ELISA). ACPA responses in purified anti-CCP2 IgG eluates were measured by ELISA in 10 plasma samples (left panel) and 11 synovial fluid samples (right panel). Anti-CCP2 lgG response (top panel), anti-CEP-1 IgG response, anti-Cit-vim IgG response, anti-Cit-fib IgG response, and anti-Cit-C1 lgG response (bottom panel) are shown. X-axis shows anti-CCP2 IgG eluate concentrations $(\mu \mathrm{g} / \mathrm{mL})$. Y-axis shows ACPA levels (AU/mL). Anti-CCP2 lgG eluates highlighted in red indicate samples with particularly weak binding to the CCP2 ELISA plates. CCP, cyclic citrullinated peptide; CEP-1, citrullinated a-enolase peptide 1 (amino acid 5-21); Cit-C1, citrullinated triple helical peptide/ epitope on collagen type II (amino acid 359-369); Cit-fib, citrullinated fibrinogen peptide ( $\beta$-chain, amino acid 36-52); Cit-vim, citrullinated vimentin peptide (amino acid 60-75); lgG, immunoglobulin G.

citrullinated, but not native human fibrinogen $\alpha$ - and $\beta$-chains, $\alpha$-enolase, and mutated vimentin, whereas the corresponding CCP2 column flow-through IgG pool bound neither the citrullinated nor the native proteins (Figure 3).

\section{Purified anti-CCP2 IgGs bind antigen targets in RA} synovial tissue and SF cells

A pool of 26 purified anti-CCP2 IgG eluate fractions from $\mathrm{SF}$ and the corresponding flow-through IgG pool were biotinylated and tested for the ability to bind in vivo-

Table 2 ACPA IgG responses (AU/mL) in 10 plasma and 11 synovial fluid samples "pre" and "post" CCP2 affinity column purification

\begin{tabular}{|c|c|c|c|c|c|c|c|c|c|c|}
\hline \multirow[t]{2}{*}{ Plasma } & \multicolumn{2}{|c|}{$C C P$} & \multicolumn{2}{|c|}{ CEP-1 } & \multicolumn{2}{|c|}{ Cit-vim } & \multicolumn{2}{|c|}{ Cit-fib } & \multicolumn{2}{|c|}{ Cit-C1 } \\
\hline & Pre & Post & Pre & Post & Pre & Post & Pre & Post & Pre & Post \\
\hline RA 1 & $>3,200$ & $>3,200$ & 142 & 254 & $<10$ & 45 & 17 & 417 & 17 & 122 \\
\hline RA 2 & 505 & $>3,200$ & 104 & 1,207 & $<10$ & 101 & 18 & 92 & $<10$ & 20 \\
\hline RA 3 & $>3,200$ & $>3,200$ & 44 & 225 & 18 & 59 & 101 & 518 & 333 & 333 \\
\hline RA 4 & $>3,200$ & $>3,200$ & 97 & 1,052 & 30 & 65 & 33 & 79 & 77 & 195 \\
\hline RA 5 & $>3,200$ & $>3,200$ & 24 & 30 & 21 & 35 & 104 & 139 & 114 & 172 \\
\hline RA 6 & $>3,200$ & $>3,200$ & 13 & 43 & 30 & 70 & 18 & 36 & $<10$ & $<10$ \\
\hline RA 7 & $>3,200$ & $>3,200$ & 140 & 69 & 107 & 348 & 282 & 155 & 170 & 86 \\
\hline RA 8 & $>3,200$ & $>3,200$ & 11 & 15 & $<10$ & 27 & 42 & 168 & 17 & 26 \\
\hline RA 9 & 763 & $>3,200$ & 17 & 135 & $<10$ & 59 & $<10$ & 79 & 73 & 222 \\
\hline RA 10 & 1,151 & $>3,200$ & $<10$ & 24 & $<10$ & 47 & $<10$ & 92 & 18 & 38 \\
\hline Median & 3,200 & 3,200 & 34 & 102 & 9 & 59 & 25.5 & 115.5 & 45.5 & 104 \\
\hline \multirow[t]{2}{*}{ Synovial fluid } & \multicolumn{2}{|c|}{$\mathrm{CCP}$} & \multicolumn{2}{|c|}{ CEP-1 } & \multicolumn{2}{|c|}{ Cit-vim } & \multicolumn{2}{|c|}{ Cit-fib } & \multicolumn{2}{|c|}{ Cit-C1 } \\
\hline & Pre & Post & Pre & Post & Pre & Post & Pre & Post & Pre & Post \\
\hline RA 11 & 2,447 & $>3,200$ & 173 & 447 & 31 & 14 & 28 & 163 & $<10$ & $<10$ \\
\hline RA 12 & 311 & 1,780 & $<10$ & 117 & 15 & 131 & $<10$ & 156 & $<10$ & $<10$ \\
\hline RA 13 & 596 & $>3,200$ & 15 & 1,339 & 19 & 32 & $<10$ & 34 & $<10$ & 185 \\
\hline RA 14 & 1,196 & $>3,200$ & 22 & 109 & $<10$ & $<10$ & $<10$ & 152 & 30 & 18 \\
\hline RA 15 & 508 & $>3,200$ & 67 & 183 & $<10$ & 191 & $<10$ & 253 & $<10$ & 200 \\
\hline RA 16 & 435 & $>3,200$ & 16 & 46 & $<10$ & 40 & $<10$ & $<10$ & $<10$ & 111 \\
\hline RA 17 & 378 & 1,311 & 51 & 610 & $<10$ & 167 & $<10$ & 97 & $<10$ & 44 \\
\hline RA 18 & 592 & 1,282 & 688 & 900 & $<10$ & 17 & $<10$ & 17 & $<10$ & 48 \\
\hline RA 19 & 1,084 & $>3,200$ & 85 & 339 & 23 & 115 & 17 & 187 & 19 & 62 \\
\hline RA 20 & 515 & 1,537 & 67 & 1,271 & $<10$ & 17 & $<10$ & 21 & $<10$ & 80 \\
\hline RA 21 & 566 & 897 & 101 & 900 & $<10$ & 113 & $<10$ & 80 & $<10$ & 146 \\
\hline Median & 566 & 3,200 & $67^{a}$ & $447^{a}$ & 0 & 40 & 0 & 97 & 0 & 62 \\
\hline
\end{tabular}

"Pre" samples were tested at a dilution of 1:100, and "Post" samples were tested at $10 \mu \mathrm{g} / \mathrm{mL}$. Cutoffs for positivity: $25 \mathrm{AU} / \mathrm{mL}$ (CCP) and 10 AU/mL (CEP-1, Cit-vim, Cit-fib, and Cit-C1). ${ }^{a}$ Anti-CEP-1 lgG levels in synovial fluid were significantly higher than the other anti-citrullinated protein/peptide antibody (ACPA) levels $(P<0.01)$. CCP, cyclic citrullinated peptide; CEP-1, citrullinated a-enolase peptide 1 (amino acid 5-21); Cit-C1, citrullinated triple helical peptide/epitope on collagen type II (amino acid 359-369); Cit-fib, citrullinated fibrinogen peptide ( $\beta$-chain, amino acid 36-52); Cit-vim, citrullinated vimentin peptide (amino acid 60-75); IgG, immunoglobulin G; RA, rheumatoid arthritis. 


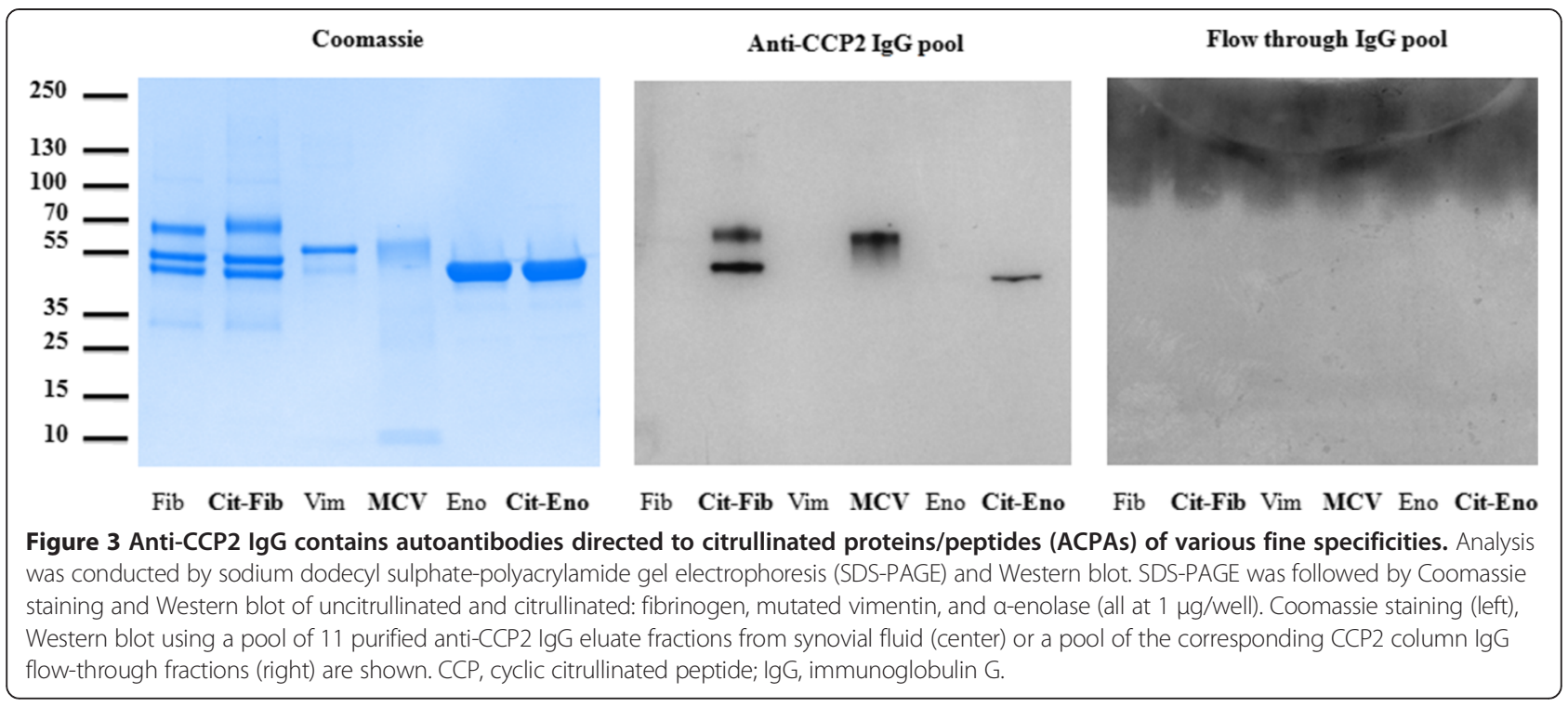

generated citrullinated proteins by immunohisto-/immunocytochemistry (Figure 4). Infiltrating cells in inflamed RA synovial tissue stained positive using the ACPA IgG pool, whereas staining with the corresponding flowthrough IgG pool was negative. Likewise, RA SF cells stained positive with the ACPA pool but negative with the flow-through pool.

\section{Discussion}

Using an efficient and robust method to affinity-purify ACPAs, we were able to determine the concentration and the proportion of CCP2-reactive IgG molecules in plasma and SF of patients with RA. Based on the samples analyzed in our study, approximately $2 \%$ of the IgG pool in both plasma and SF are CCP2-reactive, which corresponds to anti-CCP2 IgG concentrations of 0.2 and $0.06 \mathrm{mg} / \mathrm{mL}$ (median values) in plasma and SF, respectively. These concentrations are somewhat higher than what was reported in another study [22] but are in line with what has been described more recently [29] and in studies of other antigen-specific IgG responses [31,32]. In $\mathrm{SF}$ samples from four patients, more than $6 \%$ of the IgG molecules were CCP2-reactive. This high proportion of ACPA may suggest a local production or enrichment (or both) of autoantibodies in the inflamed joint, which also has been proposed in a previous study, in which higher ACPA levels were detected in SF, compared to serum, after normalization against total IgG [7]. This observation is supported by a recent study, in which the ACPA-specific memory B cells were estimated to constitute as much as $30 \%$ of the total memory B-cell pool in RA SF [33].

Our ELISA data formally demonstrate that the CCP2 peptides commonly used in diagnostic ELISAs de facto act as surrogate antigens for the four most extensively studied ACPA fine specificities in RA: anti-CEP-1, antiCit-vim, anti-Cit-fib, and anti-Cit-C1 antibodies. The finding that purified anti-CCP2 IgG identifies citrullinated fibrinogen, $\alpha$-enolase, and mutated vimentin by immunoblotting confirms and extends data previously published by Ioan-Facsinay and colleagues, who could show that antibodies eluted from CCP2 ELISA plates bound to citrullinated fibrinogen [22].

The differences seen in binding to CCP2 between the different anti-CCP2 IgG eluates when analyzed by using the CCPlus $^{\oplus}$ ELISA suggest that differences in affinity for the CCP2 peptides exist between patients, which in turn may depend on the composition of ACPA fine specificities in the different samples. However, we have not been able to identify a specific ACPA profile corresponding to strong CCP2 binding. We observed, on the other hand, that several anti-CCP2 IgG eluates with weak binding to CCP2 showed particularly strong binding to CEP-1, which may suggest that anti-CEP-1 antibodies have lower affinity for the CCP2 peptides compared with the other ACPA fine specificities investigated here. Still, it is important to note that all antiCEP-1 antibodies were captured by the CCP2 column, as no CEP-1 reactivity was detected in the flow-through fractions.

In SF and in anti-CCP2 IgG purified from SF, reactivity with the CEP-1 peptide was significantly stronger than reactivity with the other citrullinated peptides. These data are in line with those of a recently published study by Amara and colleagues, demonstrating that CEP-1 reactive B-cell clones were more commonly isolated from RA SF than cit-vim and cit-fib reactive B-cell clones [33]. The results in both their study and our study may 


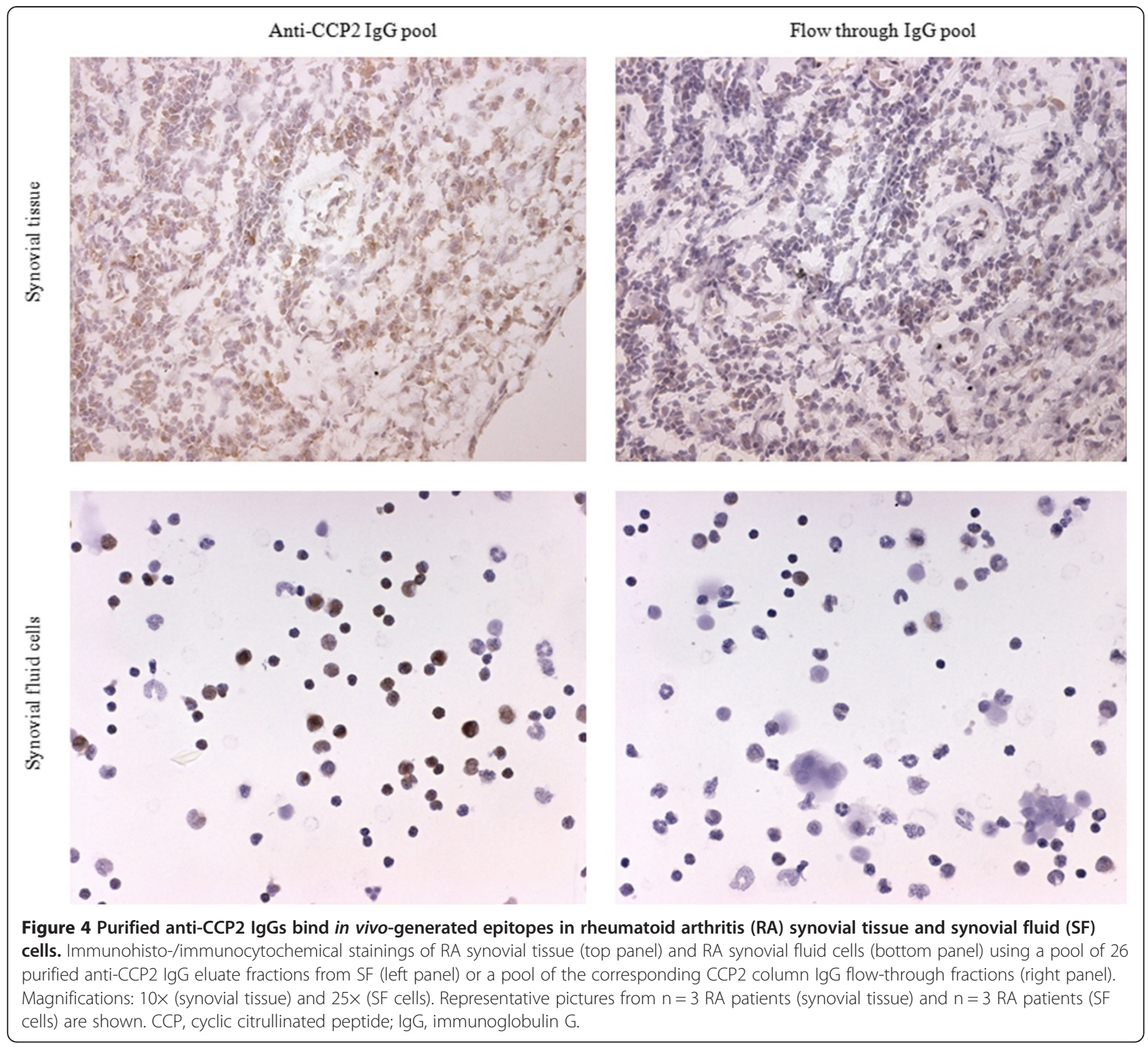

be influenced by how well the different peptide ELISAs perform. Still, such differences were not seen in plasma or in anti-CCP2 IgG purified from plasma. Hence, the data suggest a specific enrichment or production (or both) of anti-CEP-1 antibodies in the joint.

\section{Conclusions}

Our study demonstrates that anti-CCP2 reactive antibodies constitute at least four different RA-associated ACPA fine specificities and furthermore that anti-CCP2 IgGs bind in vivo-generated antigens in the rheumatoid joint. Isolation of human ACPA by using affinity columns with conjugated citrullinated antigens, such as the CCP2 column described here, or the mutated citrullinated vimentin column, previously described by Harre and colleagues [34], or the more recently described purification of ACPA reactive with various citrullinated CII epitopes, which were shown to bind rheumatoid cartilage [35], will allow important functional and structural in vitro and in vivo studies aimed at elucidating the mode of action and pathogenic potential of human ACPA.

\section{Abbreviations}

ACPA: anti-citrullinated protein/peptide antibody; CCP: cyclic citrullinated peptide; CEP-1: citrullinated a-enolase peptide 1 (amino acid 5-21); Cll: collagen type II; Cit-C1: citrullinated triple helical peptide/epitope on collagen type II (amino acid 359-369); Cit-fib: citrullinated fibrinogen peptide ( $\beta$-chain, amino acid 36-52); Cit-vim: citrullinated vimentin peptide (amino acid 60-75);

DTT: dithiothreitol; ECL: enhanced chemiluminescence; ELISA: enzyme-linked immunosorbent assay; HRP: horseradish peroxidase; lgG: immunoglobulin G; LDS: lithium dodecyl sulphate; PAD2: peptidylarginine deiminase 2; PBS: phosphate-buffered saline; RA: rheumatoid arthritis; SDS-PAGE: sodium dodecyl sulphate-polyacrylamide gel electrophoresis; SF: synovial fluid. 


\section{Competing interests}

Euro-Diagnostica AB markets diagnostic tests based on the CCP2 antigen. $\mathrm{KL}$ is co-inventor of patent US12/524,465, describing the diagnostic use of the CEP-1 epitope. RH is the inventor of patent US7/148,020B2, describing the diagnostic use of the $\mathrm{C} 1$ epitope. The other authors declare that they have no competing interests.

\section{Authors' contributions}

$E O$ and CFC had main responsibility for the experimental set-up and optimization and laboratory work of purifying anti-CCP2 lgG and analyzed the data and produced Table 1 and Figure 1. ER and NK performed all ELISAs and the Western blot, analyzed the data, and produced Table 2 and Figures 2 and 3. LI developed and set up the in-house ELISAs and participated in analyzing and interpreting the ELISA data. RH and KSN provided and supervised the production of recombinant a-enolase as well as the Cit-C1 triple-helical peptide and contributed to the design of the Cit-C1 ELISA. ME biotinylated the purified ACPA and FT IgG, performed the immunohisto-/ immunocytochemistry, and produced Figure 4 . UH and GS provided the recombinant vimentin and performed the in vitro citrullination of vimentin. AIC and VM had the main responsibility for the collection of plasma and SFs from patients with RA, including the identification of suitable patients. YS produced the CCP2 column and contributed to the design of the ACPA affinity purification experiments. LK and P-JJ, together with $\mathrm{KL}$, designed the study and supervised the work. KL had main responsibility for the study, including design, experimental set-up, analyses, figures, tables, supervising, and writing of the manuscript. All authors participated in critically reading and reviewing the manuscript and approved the final version of the manuscript.

\section{Acknowledgments}

The authors wish to thank patients, research nurses, and research technicians for their contributions to the study; Holger Bang at Orgentec (Mainz, Germany) for producing recombinant vimentin; and Sabrina Haag at the Department of Medical Biochemistry and Biophysics, Karolinska Institutet, for providing recombinant a-enolase. This work was supported by grants from the Swedish Research Council, Vinnova, the Strategic Foundations of Sweden, the Swedish Rheumatic Foundation, the Marianne and Marcus Wallenberg Foundation, King Gustav the V's 80 years fund, the EU-funded projects Gums\&Joints (FP7-Health-2010-261460) and MasterSwitch (FP6-Health-2007-2.4.5-12) and the IMI program BTCure (115142-2). The work of GS was additionally supported by SPP1468 (Immunobone) of the German Research Council and the Marie Curie Grant Osteoimmune.

\section{Author details}

'Rheumatology Unit, Department of Medicine, Karolinska Institutet, CMM L8:04, Karolinska University Hospital Solna, 17176 Stockholm, Sweden. 2Department of Medical Biochemistry and Biophysics, Karolinska Institutet, Scheeles väg 2, Karolinska Institutet, 17177 Stockholm, Sweden. ${ }^{3}$ Department of Internal Medicine 3, University of Erlangen-Nuremberg, Ulmenweg 18, 91054 Erlangen, Germany. ${ }^{4}$ Euro-Diagnostica AB, Euro Diagnostica AB, P.O. Box 50117, 20211 Malmö, Sweden. ${ }^{5}$ Postal address: Rheumatology Unit, Department of Medicine, Karolinska Institutet, Karolinska University Hospital Solna, CMM L8:04, Karolinska University Hospital Solna, 17176 Stockholm, Sweden.

Received: 20 November 2013 Accepted: 8 July 2014 Published: 12 August 2014

\section{References}

1. Schellekens GA, de Jong BA, van den Hoogen FH, van de Putte $L B$, van Venrooij WJ: Citrulline is an essential constituent of antigenic determinants recognized by rheumatoid arthritis-specific autoantibodies. J Clin Invest 1998, 101:273-281.

2. Schellekens GA, Visser $H$, de Jong BA, van den Hoogen FH, Hazes JM, Breedveld FC, van Venrooij WJ: The diagnostic properties of rheumatoid arthritis antibodies recognizing a cyclic citrullinated peptide. Arthritis Rheum 2000, 43:155-163.

3. Klareskog L, Ronnelid J, Lundberg K, Padyukov L, Alfredsson L: Immunity to citrullinated proteins in rheumatoid arthritis. Annu Rev Immunol 2008, 26:651-675
4. Rantapaa-Dahlqvist S, de Jong BA, Berglin E, Hallmans G, Wadell G, Stenlund $H$, Sundin U, van Venrooij WJ: Antibodies against cyclic citrullinated peptide and IgA rheumatoid factor predict the development of rheumatoid arthritis. Arthritis Rheum 2003, 48:2741-2749.

5. Nielen MM, van Schaardenburg D, Reesink HW, van de Stadt RJ, van der Horst-Bruinsma IE, de Koning MH, Habibuw MR, Vandenbroucke JP, Dijkmans BA: Specific autoantibodies precede the symptoms of rheumatoid arthritis: a study of serial measurements in blood donors. Arthritis Rheum 2004, 50:380-386.

6. Avouac J, Gossec L, Dougados M: Diagnostic and predictive value of anti-cyclic citrullinated protein antibodies in rheumatoid arthritis: a systematic literature review. Ann Rheum Dis 2006, 65:845-851.

7. Snir O, Widhe M, Hermansson M, von Spee C, Lindberg J, Hensen S, Lundberg K, Engstrom A, Venables PJ, Toes RE, Holmdahl R, Klareskog L, Malmström V: Antibodies to several citrullinated antigens are enriched in the joints of rheumatoid arthritis patients. Arthritis Rheum 2010, 62:44-52.

8. Mahdi H, Fisher BA, Kallberg H, Plant D, Malmstrom V, Ronnelid J, Charles P, Ding B, Alfredsson L, Padyukov L, Symmons DP, Venables PJ, Klareskog L, Lundberg K: Specific interaction between genotype, smoking and autoimmunity to citrullinated alpha-enolase in the etiology of rheumatoid arthritis. Nat Genet 2009, 41:1319-1324.

9. van der Woude D, Alemayehu WG, Verduijn W, de Vries RR, HouwingDuistermaat JJ, Huizinga TW, Toes RE: Gene-environment interaction influences the reactivity of autoantibodies to citrullinated antigens in rheumatoid arthritis. Nat Genet 2010, 42:814-816. author reply 816.

10. van de Stadt $L A$, van der Horst $A R$, de Koning $M H$, Bos WH, Wolbink GJ, van de Stadt RJ, Pruijn GJ, Dijkmans BA, van Schaardenburg D, Hamann D: The extent of the anti-citrullinated protein antibody repertoire is associated with arthritis development in patients with seropositive arthralgia. Ann Rheum Dis 2011, 70:128-133.

11. Snir O, Widhe $M$, von Spee $C$, Lindberg J, Padyukov L, Lundberg $K$ Engstrom A, Venables PJ, Lundeberg J, Holmdahl R, Klareskog L, Malmström $\checkmark$ : Multiple antibody reactivities to citrullinated antigens in sera from patients with rheumatoid arthritis: association with HLA-DRB1 alleles. Ann Rheum Dis 2009, 68:736-743.

12. Willemze A, Bohringer S, Knevel R, Levarht EW, Stoeken-Riisbergen G, Houwing-Duistermaat JJ, van der Helm-van Mil AH, Huizinga TW, Toes RE, Trouw LA: The ACPA recognition profile and subgrouping of ACPA-positive RA patients. Ann Rheum Dis 2012, 71:268-274.

13. Lundberg K, Kinloch A, Fisher BA, Wegner N, Wait R, Charles P, Mikuls TR, Venables PJ: Antibodies to citrullinated alpha-enolase peptide 1 are specific for rheumatoid arthritis and cross-react with bacterial enolase. Arthritis Rheum 2008, 58:3009-3019.

14. Kinloch A, Lundberg K, Wait R, Wegner N, Lim NH, Zendman AJ, Saxne T, Malmstrom V, Venables PJ: Synovial fluid is a site of citrullination of autoantigens in inflammatory arthritis. Arthritis Rheum 2008, $58: 2287-2295$

15. Masson-Bessiere C, Sebbag M, Girbal-Neuhauser E, Nogueira L, Vincent C, Senshu T, Serre G: The major synovial targets of the rheumatoid arthritis-specific antifilaggrin autoantibodies are deiminated forms of the alpha- and beta-chains of fibrin. J Immunol 2001, 166:4177-4184.

16. Vossenaar ER, Despres N, Lapointe E, van der Heijden A, Lora M, Senshu T, van Venrooij WJ, Menard HA: Rheumatoid arthritis specific anti-Sa antibodies target citrullinated vimentin. Arthritis Res Ther 2004, 6:R142-R150.

17. Burkhardt H, Sehnert B, Bockermann R, Engstrom A, Kalden JR, Holmdahl R: Humoral immune response to citrullinated collagen type II determinants in early rheumatoid arthritis. Eur J Immunol 2005, 35:1643-1652.

18. Shoda H, Fujio K, Shibuya M, Okamura T, Sumitomo S, Okamoto A, Sawada T, Yamamoto K: Detection of autoantibodies to citrullinated $\mathrm{BiP}$ in rheumatoid arthritis patients and pro-inflammatory role of citrullinated BiP in collagen-induced arthritis. Arthritis Res Ther 2011, 13:R191.

19. Iaccarino L, Ghirardello A, Canova M, Zen M, Bettio S, Nalotto L, Punzi L, Doria A: Anti-annexins autoantibodies: their role as biomarkers of autoimmune diseases. Autoimmun Rev 2011, 10:553-558.

20. Pratesi F, Dioni I, Tommasi C, Alcaro MC, Paolini I, Barbetti F, Boscaro F, Panza F, Puxeddu I, Rovero P, Migliorini P: Antibodies from patients with rheumatoid arthritis target citrullinated histone 4 contained in neutrophils extracellular traps. Ann Rheum Dis 2013, 73:1414-1422. 
21. Lundberg K, Bengtsson C, Kharlamova N, Reed E, Jiang X, Kallberg $H$, Pollak-Dorocic I, Israelsson L, Kessel C, Padyukov L, Holmdahl R, Alfredsson L, Klareskog L: Genetic and environmental determinants for disease risk in subsets of rheumatoid arthritis defined by the anticitrullinated protein/ peptide antibody fine specificity profile. Ann Rheum Dis 2013, 72:652-658.

22. Loan-Facsinay A, El-Bannoudi H, Scherer HU, van der Woude D, Menard HA, Lora M, Trouw LA, Huizinga TW, Toes RE: Anti-cyclic citrullinated peptide antibodies are a collection of anti-citrullinated protein antibodies and contain overlapping and non-overlapping reactivities. Ann Rheum Dis 2011, 70:188-193.

23. Arnett FC, Edworthy SM, Bloch DA, McShane DJ, Fries JF, Cooper NS, Healey LA, Kaplan SR, Liang MH, Luthra HS, Medsger TA Jr, Mitchell DM, Neustadt DH, Pinals RS, Schaller JG, Sharp JT, Wilder RL, Hunder GG: The American Rheumatism Association 1987 revised criteria for the classification of rheumatoid arthritis. Arthritis Rheum 1988, 31:315-324

24. Aletaha D, Neogi T, Silman AJ, Funovits J, Felson DT, Bingham CO 3rd, Birnbaum NS, Burmester GR, Bykerk VP, Cohen MD, Combe B, Costenbader KH, Dougados M, Emery P, Ferraccioli G, Hazes JM, Hobbs K, Huizinga TW, Kavanaugh A, Kay J, Kvien TK, Laing T, Mease P, Ménard HA, Moreland LW, Naden RL, Pincus T, Smolen JS, StanislawskaBiernat E, Symmons D, et al: 2010 rheumatoid arthritis classification criteria: an American College of Rheumatology/European League Against Rheumatism collaborative initiative. Ann Rheum Dis 2010, 69:1580-1588.

25. Aletaha D, Neogi T, Silman AJ, Funovits J, Felson DT, Bingham CO 3rd, Birnbaum NS, Burmester GR, Bykerk VP, Cohen MD, Combe B, Costenbader KH, Dougados M, Emery P, Ferraccioli G, Hazes JM, Hobbs K, Huizinga TW, Kavanaugh A, Kay J, Kvien TK, Laing T, Mease P, Ménard HA, Moreland LW, Naden RL, Pincus T, Smolen JS, StanislawskaBiernat E, Symmons D, et al: 2010 rheumatoid arthritis classification criteria: an American College of Rheumatology/European League Against Rheumatism collaborative initiative. Arthritis Rheum 2010, 62:2569-2581.

26. Page $M$, Thorpe R: Purification of IgG by precipitation with sodium sulphate or ammonium sulphate. In The Protein Protocols Handbook Edited by Walker JM. Totowa, NJ: Humana Press Inc; 2002:983-985.

27. Hermansson M, Artemenko K, Ossipova E, Eriksson H, Lengqvist J, Makrygiannakis D, Catrina Al, Nicholas AP, Klareskog L, Savitski M, Zubarev RA, Jakobsson PJ: MS analysis of rheumatoid arthritic synovial tissue identifies specific citrullination sites on fibrinogen. Proteomics Clin Appl 2010, 4:511-518.

28. Scherer HU, van der Woude D, loan-Facsinay A, el Bannoudi H, Trouw LA, Wang J, Haupl T, Burmester GR, Deelder AM, Huizinga TW, Wuhrer $M$, Toes RE: Glycan profiling of anti-citrullinated protein antibodies isolated from human serum and synovial fluid. Arthritis Rheum 2010, 62:1620-1629

29. Willemze A, Shi J, Mulder M, Stoeken-Rijsbergen G, Drijfhout JW, Huizinga TW, Trouw LA, Toes RE: The concentration of anticitrullinated protein antibodies in serum and synovial fluid in relation to total immunoglobulin concentrations. Ann Rheum Dis 2013, 72:1059-1063.

30. Veys EM: Comparative investigation of protein concentration in serum and synovial fluid. Scand J Rheumatol 1974, 3:1-12.

31. Amiral J, Pouplard C, Vissac AM, Walenga JM, Jeske W, Gruel Y: Affinity purification of heparin-dependent antibodies to platelet factor 4 developed in heparin-induced thrombocytopenia: biological characteristics and effects on platelet activation. Br J Haematol 2000, 109:336-341.

32. Brinkman DM, der Zijde CM J-v, ten Dam MM, te Boekhorst PA, ten Cate R, Wulffraat NM, Hintzen RQ, Vossen JM, van Tol MJ: Resetting the adaptive immune system after autologous stem cell transplantation: lessons from responses to vaccines. J Clin Immunol 2007, 27:647-658.
33. Amara K, Steen J, Murray F, Morbach H, Fernandez-Rodriguez BM, Joshua V, Engstrom M, Snir O, Israelsson L, Catrina Al, Wardemann H, Corti D, Meffre E, Klareskog L, Malmström V: Monoclonal IgG antibodies generated from joint-derived $B$ cells of RA patients have a strong bias toward citrullinated autoantigen recognition. J Exp Med 2013, 210:445-455.

34. Harre U, Georgess D, Bang H, Bozec A, Axmann R, Ossipova E, Jakobsson PJ, Baum W, Nimmerjahn F, Szarka E, Sarmay G, Krumbholz G, Neumann E, Toes R, Scherer HU, Catrina Al, Klareskog L, Jurdic P, Schett G: Induction of osteoclastogenesis and bone loss by human autoantibodies against citrullinated vimentin. J Clin Invest 2012, 122:1791-1802.

35. Haag S, Schneider N, Mason DE, Tuncel J, Andersson IE, Peters EC, Burkhardt $H$, Holmdahl R: Mass spectrometric analysis of citrullinated type II collagen reveals new citrulline-specific autoantibodies, which bind to human arthritic cartilage. Arthritis Rheum 2014, 66:1440-1449.

\section{doi:10.1186/ar4683}

Cite this article as: Ossipova et al:: Affinity purified anti-citrullinated protein/peptide antibodies target antigens expressed in the rheumatoid joint. Arthritis Research \& Therapy 2014 16:R167.

\section{Submit your next manuscript to BioMed Central and take full advantage of:}

- Convenient online submission

- Thorough peer review

- No space constraints or color figure charges

- Immediate publication on acceptance

- Inclusion in PubMed, CAS, Scopus and Google Scholar

- Research which is freely available for redistribution

Submit your manuscript at www.biomedcentral.com/submit
() Biomed Central 